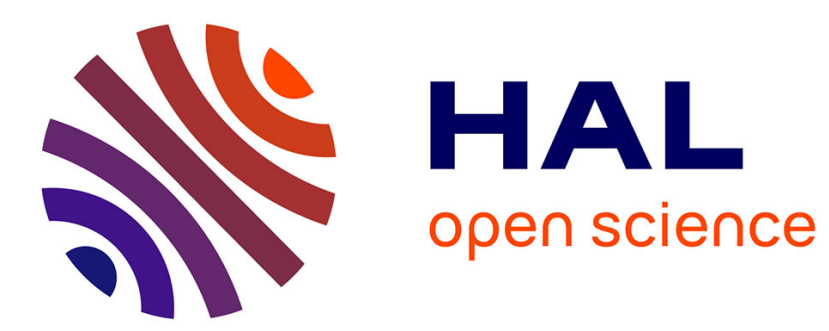

\title{
NMR INVESTIGATIONS OF NATIVE AND DOPED POLYACETYLENE FILMS
}

\author{
M. Ziliox, B. François, C. Mathis, B. Meurer, P. Spegt, G. Weill
}

\section{To cite this version:}

M. Ziliox, B. François, C. Mathis, B. Meurer, P. Spegt, et al.. NMR INVESTIGATIONS OF NATIVE AND DOPED POLYACETYLENE FILMS. Journal de Physique Colloques, 1983, 44 (C3), pp.C3361-C3-364. 10.1051/jphyscol:1983373 . jpa-00223034

\section{HAL Id: jpa-00223034 https://hal.science/jpa-00223034}

Submitted on 1 Jan 1983

HAL is a multi-disciplinary open access archive for the deposit and dissemination of scientific research documents, whether they are published or not. The documents may come from teaching and research institutions in France or abroad, or from public or private research centers.
L'archive ouverte pluridisciplinaire HAL, est destinée au dépôt et à la diffusion de documents scientifiques de niveau recherche, publiés ou non, émanant des établissements d'enseignement et de recherche français ou étrangers, des laboratoires publics ou privés. 


\title{
NMR INVESTIGATIONS OF NATIVE AND DOPED POLYACETYLENE FILMS
}

\author{
M. Ziliox, B. François, C. Mathis, B. Meurer, P. Spegt and G. Weill \\ Centre de Recherches sur les Macromolécules, 6 Rue Boussingault, F-67083 \\ Strasbourg, France
}

Résumé - Nous avons mesuré le second moment de la raie RMN du proton et les temps de relaxation spin-réseau du proton, du deutérium et du carbone 13 dans des échantilions de polyacétylène normaux, deutểés et enrichis en ${ }^{13} \mathrm{C}$. Pour les échantillons cis et trans normaux, progressivement dopés à l'jode ou au sodium, la variation du second moment met en évidence l'isomérisation induite par le dopage et le gonflement du réseau dû à T'intercalation du dopant entre les chaînes polymẽres. La variation du temps de relaxation du proton s'explique par l'évolution du nombre et de la mobilité des solitons neutres au cours du dopage. Pour le deutérium et le carbone 13, par contre, la relaxation n'est pas monoexponentielle et elle s'exploite parfajtement en deux exponentielles de constantes de temps 1,5 et $8,6 \mathrm{~s}$ pour $2 \mathrm{H}$ et 0,3 et $1,5 \mathrm{~s}$ pour ${ }^{13} \mathrm{C}$.

Abstract - Our results concern the second moment of the proton NMR Iine and the relaxation time $\mathrm{T}_{1}$ of protonated, deuterated and ${ }^{13} \mathrm{C}$ enriched polyacetylenes. For the protonated cis and trans samples, progressively doped with iodine or sodium, the changes in the second moment reveal doping induced isomerization and further swelling of the lattice; the $T_{1}$ measurements are consistent with a decrease in number and mobility of neutral solitons upon doping.

Our preliminary results on deuterated and ${ }^{13} \mathrm{C}$ enriched samples show that, whereas proton magnetization recovers in an exponential way, ${ }^{2} \mathrm{H}$ and ${ }^{13} \mathrm{C}$ relaxations are well fitted by a double exponential function with time constants 1.5 and $8.6 \mathrm{~s}$ for the deuterated samples and 0.3 and $1.5 \mathrm{~s}$ for ${ }^{13} \mathrm{C}$ nuclei.

All our samples were prepared according to Shirakawa's technique : the exact procedure has been described in another report from our laboratory (1).

NMR measurements were performed on a Bruker SXP spectrometer working at $60 \mathrm{MHz}$ for the proton and on a Bruker CXP 200 at 30.7 and $50.3 \mathrm{MHz}$ for the deuterium and $13 \mathrm{C}$. The signal was processed on a Nicolet BNC 12 minicomputer, after acquisition and digitalization by an 8 bit - $10 \mathrm{MHz}$ Bruker BC $100 \mathrm{q}$ converter.

The second moment of the proton line was measured by fitting the free induction decay (FID) following the spectrometer deadtime (typically $5 \mu \mathrm{s}$ ) to an even polynomial of degree 10 , and extrapolating it to time 0 taken at the middle of the pulse (2).

The relaxation curves, obtained by the inversion-recovery technique, were fitted to one or two exponentials, according to the best fit.

\section{I - IODINE AND SODIUM DOPED SAMPLES}

We performed these experiments in order to check the amount of dopant necessary to isomerize an initially cis-sample and we compared the structural effects of the dopants, benzophenone sodium being known to be a mild and easily controlable doping agent.

The second moments and proton relaxation rates of progressively doped samples have been measured at $200 \mathrm{~K}$. 

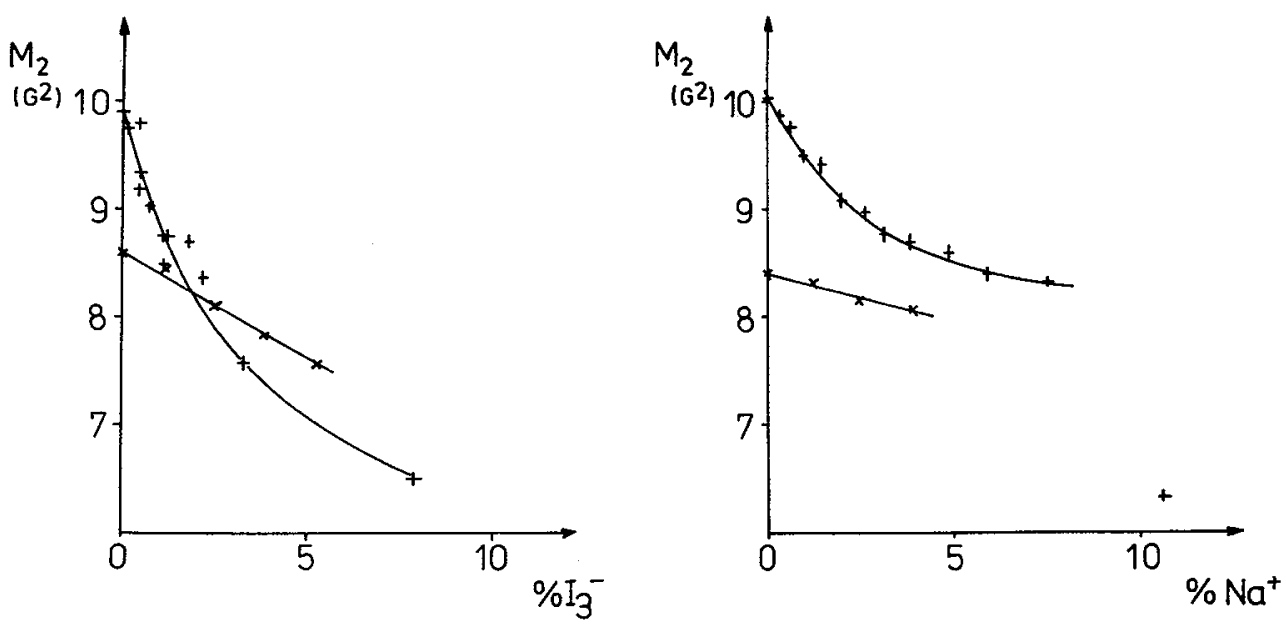

Figs. 1 and 2 - Dependence of the second moment $M_{2}$ of $(\mathrm{CH})_{x}$ cis $(+)$ and trans $(x)$ films with iodine (Fig. 1) and sodium (Fig. 2) contents.

In both cases, for the initially cis-samples, the second moment decreases faster in the initial range of doping (up to $5 \%$ of atomic iodine and $3 \%$ of sodium) and reaches values typical of trans samples. These values are in good agreement with IR determinations of the cis-trans content of such doped samples. The further decreases are most probably due to swelling of the lattice by the dopant.

Notice also that the second moment of cis and trans films decreases faster in the case of iodine doping, because the doping agent $I_{3}^{-}$is much larger than $\mathrm{Na}^{+}$.
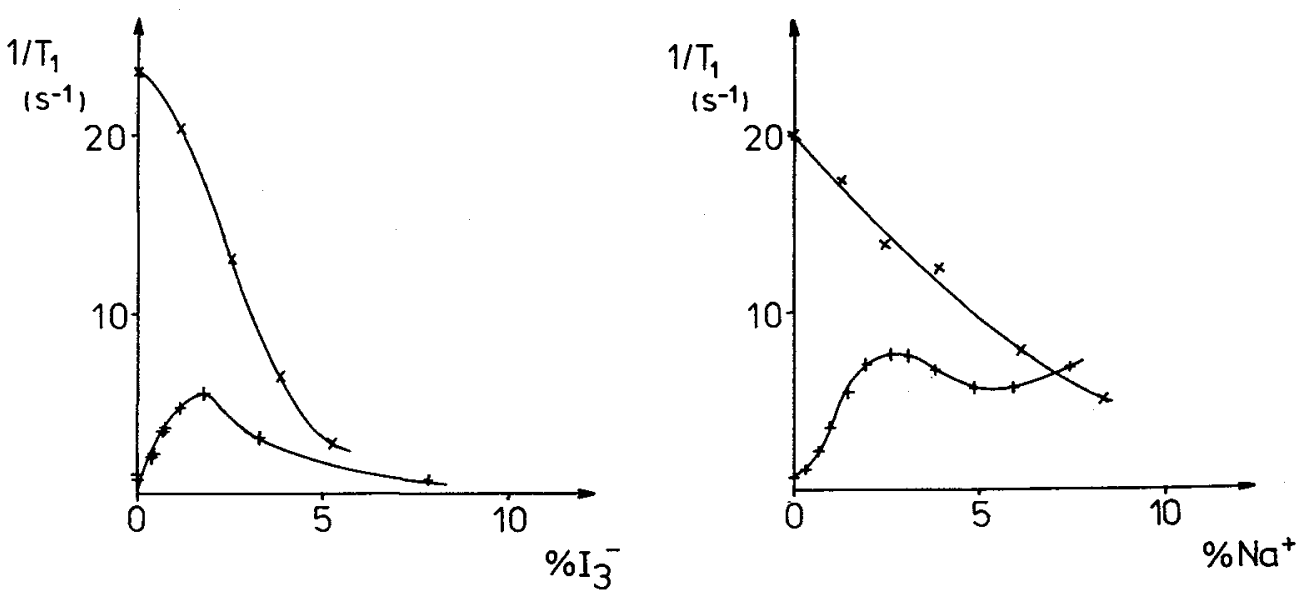

Figs. 3 and 4 - Dependence of relaxation rate $T_{1}^{-1}$ of $(\mathrm{CH})_{x} \operatorname{cis}(+)$ and $\operatorname{trans}(x)$ films with iodine (Fig. 3) and sodium (Fig. 4) contents.

The recovery of the longitudinal magnetization is exponential over one decade in the whole doping range.

For the trans isomer, the relaxation rate reveals a monotonic variation, which can be explained by the change in number and mobility of neutral solitons, which are transformed into spinless charged solitons upon doping. 
Cis samples show a non monotonic variation of $T_{1}$, the mechanism of relaxation being complicated by the initial isomerization. At the highest doping ratio, the relaxation rates are similar for both isomers.

\section{I - ${ }^{13} \mathrm{C}$ ENRICHED POLYACETYLENE}

These experiments result from a collaboration with $F$. Masin (Bruxelles) who reported earlier measurements of proton $\mathrm{T}_{1}$ in ${ }^{1}{ }^{3} \mathrm{C}$ enriched polyacetylene (3) which differed significantly from our results on ${ }^{13} \mathrm{C}$ natural abundance samples (4). A $45 \%{ }^{13} \mathrm{C}$ enriched sample was then prepared in our laboratory, avoiding all contact with air.

The second moment of this sample is compared with our previous results (4) on unenriched cis and trans $(\mathrm{CH})_{x}$

$\begin{array}{ccc}\mathrm{M}_{2}(200 \mathrm{~K}) & { }^{13} \mathrm{C} \text { enriched } & \text { unenriched } \\ \text { cis } & 14 \mathrm{G}^{2} & 9.9 \mathrm{G}^{2} \\ \text { trans } & 12.5 \mathrm{G}^{2} & 8.5 \mathrm{G}^{2}\end{array}$

In both enriched isomers, $M_{2}$ is $4 G^{2}$ higher than in natural abundance samples. This higher value can be attributed to the dipolar broadening due to the heterogeneous interaction between the proton and its first neighbour carbon, calculated from :

$$
\Delta W_{I S}=\left(\frac{4}{15}\right) r_{I}^{2} r_{S}^{2} n^{2} S(S+1) \sum_{j} r_{i j}{ }^{-6}
$$

where $r_{i j}$ is the distance between I and S spins. This contribution is found to be on the order of $3 G^{2}$ for the given ${ }^{13} \mathrm{C}$ enrichment and is sufficient to explain the observed difference.

The proton follows an exponential relaxation with a time constant of $48 \mathrm{~ms}$ in good agreement with our reported measurements (40ms) (4). This discrepancy with Masin's results might be explained by the poorer quality of his films which resulted from the presence of oxygen.

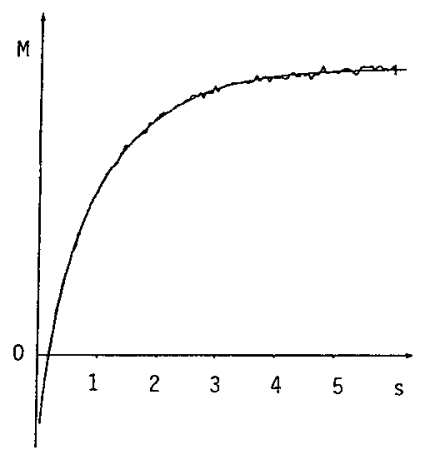

Fig. $5-{ }^{13} \mathrm{C}$ typical relaxation and its double exponential fitting.

${ }^{13} \mathrm{C}$ nuclei don't have the same relaxation behaviour as protons : their recovery is best fitted by a double exponential with a 1 to 2 amplitude ratio and time constants $0.3 \mathrm{~s}$ and $1.5 \mathrm{~s}$. 
More measurements are required to determine whether the different behaviours of the proton and ${ }^{13} \mathrm{C}$ can be explained by the presence or absence of nuclear spin transverse diffusion between chains with and without solitons.

\section{I - DEUTERATED POLYACETYLENE}

Quadrupolar interaction is usually dominant for nuclei with spin $>1 / 2$. One can therefore expect the deuterium signal to be most susceptible to fluctuations of electric field gradients. induced by the presence of a charged soliton on the carbon backbone. Quadrupolar spectra and relaxation behaviour can thus reveal interesting information about charged solitons and their mobility.

The spectra of pure cis and trans deuterated polyacetylene are very similar : the measured quadrupolar splitting is exactly the same for pure and lightly iodine doped samples $(126 \mathrm{kHz})$.

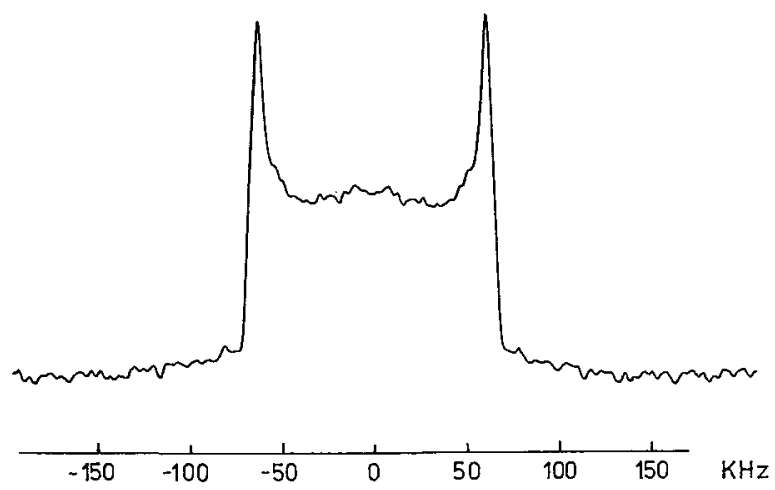

Fig. 6 - ${ }^{2} \mathrm{H}$ spectra of a deuterated cis-sample at $200 \mathrm{~K}$.

For the pure trans sample, ${ }^{2} H^{\prime}$ 's relaxation is best fitted by a double exponential. The fast relaxation concerns about $20 \%$ of the spins.

\begin{tabular}{lcc} 
& \multicolumn{2}{c}{ time constants. } \\
room temperature & $1.4 \mathrm{~s}$ & $6.5 \mathrm{~s}$ \\
low temperature & $1.6 \mathrm{~s}$ & $9 \mathrm{~s}$ \\
(200K) & &
\end{tabular}

Experimental problems mainly involving band width and detuning of the probe-head have kept us from performing $T_{1}$ measurements on doped samples.

\section{REFERENCES}

(1) FRANCOIS B., BERNARD M., ANDRE JJ., J.Chem.Phys. 75 (1981) 4142.

(2) MEURER B., SPEGT P., WEILL G., J.Physique E (in press).

(3) MASIN F., GUSMAN G., DELTOUR R., Solid State Commun. 39 (1981) 505.

(4) MEURER B., SPEGT P., WEILl G., MATHIS C., FRANCOIS B., Solid State Commun. 44 (1982) 201.

(5) ABRAGAM A., The Principles of Nuclear Magnetism, Clarendon Press, Oxford (1961). 